\title{
AMBIVALENSI PENGATURAN PEMILIHAN UMUM DI INDONESIA
}

\author{
Yusdar \\ Staf Sekretariat Komisi Pemilihan Umum Kabupaten Bone \\ Jl. Jenderal Gatot Subroto Kab. Bone, 92711, Indonesia \\ "Tel./Fax: +62-85242567747, E-mail:yusdar.law@gmail.com
}

\begin{abstract}
This study aims to understand the ambivalence of organizing elections in Indonesia so that they can conceptualize the ideal setting for conducting general elections with integrity. This research is normative legal research (normative legal research). This research was conducted by examining primary legal material and secondary legal material.

The results of the study indicate that the regulation of elections used in the administration of elections in Indonesia only emphasizes the regulation of procedural aspects. Whereas the indicators of the success of the election if the election organizers, election participants and the public as voters carry out the stages of the election in accordance with the rules of the election stage even though they set aside substantial aspects. Therefore, arrangements are needed in the administration of elections that emphasize substantial aspects, so that elections with integrity can be realized.
\end{abstract}

Key words: Ambivalencet, Election, Integrity

\begin{abstract}
Abstrak
Penelitian ini bertujuan untuk mengetahui ambivalensi pengaturan pemilihan umum di Indonesia sehingga dapat melahirkan konsep pengaturan ideal dalam mewujudkan pemilihan umum berintegritas. Penelitian ini adalah penelitian hukum normatif (normative legal research) Penelitian ini dilakukan dengan meneliti bahan hukum primer dan bahan hukum sekunder.

Hasil penelitian menunjukkan bahwa pengaturan pemilu yang digunakan dalam penyelenggaraan pemilu di Indonesia hanya menekankan pada pengaturan aspek prosedural. Bahwa indikator keberhasilan pemilu apabila Penyelenggara pemilu, peserta pemilu dan masyarakat sebagai pemilih melaksanakan tahapan pemilu sesuai dengan peraturan tahapan pemilu walaupun mengesampingkan aspek substansial. Oleh sebab itu, diperlukan pengaturan dalam penyelenggaraan pemilu yang menekankan pada aspek substansial, sehingga pemilu berintegritas dapat terwujudkan.
\end{abstract}

Kata Kunci : Ambivalensi; Pemilu; Berintegritas. 


\section{A. Pendahuluan}

Periode ketatanegaraan Indonesia membentangkan fakta normatif, bahwa era reformasi memberi harapan besar (big expectation) akan terjadinya pembaharuan dalam penyelenggaraan negara, untuk dapat mengantarkan negara Indonesia menjadi negara hukum yang demokratis. Hal ini sesuai dengan apa yang menjadi tuntutan reformasi yang dikemukakan oleh berbagai komponen masyarakat, yang sasaran akhirnya adalah tercapainya tujuan negara dan cita-cita kemerdekaan sebagaimana yang ditegaskan dalam pembukaan Undang-Undang Dasar Negara Republik Indonesia Tahun 1945 (UUD NRI Tahun 1945).

Salah satu tuntutan reformasi adalah amandemen terhadap UUD 1945. Tuntutan terhadap pelaksanaan amandemen UUD 1945 adalah tuntutan yang mempunyai dasar pemikiran teoritis konseptual dan berdasarkan pertimbangan empiris yaitu praktik ketatanegaraan Indonesia selama setengah abad. Kelemahan-kelemahan UUD 1945 secara konseptual memberi peluang lahirnya pemerintahan otoritarian. Penyelenggaraan negara berlawanan arah dari asas kedaulatan rakyat, asas negara berdasarkan atas hukum ditambah lagi proses penyelenggaraan pemilihan umum yang sangat didominasi oleh elit tertentu serta dinamika sosial dan ekonomi yang berkembang ke arah yang berlawanan dari konsep dasar yang di tetapkan dalam UUD 1945.

Pasca reformasi dan amandemen UUD $1945^{1}$ pemilihan umum di Indonesia dilaksanakan secara langsung ${ }^{2}$, umum ${ }^{3}$, bebas ${ }^{4}$, rahasia $^{5}$, jujur ${ }^{6}$, dan

1 Amandemen sebanyak empat kali : amandemen pertama pada tanggal 19 Oktober 1999, amandemen kedua pada tanggal 18 Agustus 2000, amandemen ketiga pada tanggal 10 November 2001, dan amandemen keempat pada tanggal 10 Agustus 2002. Penyebutan UUD 1945 diganti menjadi UUD NRI Tahun 1945, sebagaimana ditegaskan dalam aturan tambahan Pasal II “dengan ditetapkannya UUD ini, UUD NRI Tahun 1945 terdiri atas pembukaan dan pasal-pasal”. (Lihat : Harmailiy Ibrahim, 1987, Hukum Tata Negara Indonesia, UI, Jakarta, hal. 98)

${ }^{2}$ Langsung berarti pemilih diharuskan memberikan suaranya secara langsung dan tidak boleh diwakilkan.

${ }^{3}$ Umum berarti pemilihan umum dapat diikuti seluruh warga Negara Republik Indonesia yang sudah memiliki hak menggunakan suara.

${ }^{4}$ Bebas berarti pemilih diharuskan memberikan suaranya tanpa ada paksaan dari pihak manapun

${ }^{5}$ Rahasia berarti suara yang diberikan oleh pemilih bersifat rahasia hanya diketahui oleh si pemilih itu sendiri 
Jurnal Al-Adalah: Jurnal Hukum dan Politik Islam

Vol. 4, No. 1, Januari 2019: 21-32

P-ISSN: 2406-8802

E-mail: aladalah@iain-bone.ac.id

http://jurnal.iain-bone.ac.id/index.php/aladalah

$\operatorname{adil}^{7}$ setiap lima tahun sekali yang dimaksudkan untuk memilih anggota Dewan Perwakilan Rakyat, Dewan Perwakilan Daerah, Presiden dan Wakil Presiden dan Dewan Perwakilan Rakyat Daerah yang diselenggarakan oleh suatu komisi pemilihan umum yang bersifat nasional, tetap, dan mandiri.

Pemilihan umum adalah sebuah proses pemilihan dengan melibatkan seluruh warga negara yang akan menggunakan hak pilihnya untuk memilih wakilwakil mereka serta melibatkan para peserta pemilihan umum serta stacholders, sehingga dalam penyelenggaraan pemilihan umum tidak hanya penyelenggara yang dituntut untuk berintegritas tetapi semua komponen yang terkait. Setiap periode pelaksanaan proses pemilu selalu menyisakan permasalahan yang tiada henti dari pemilu ke pemilu tidak terkecuali permasalahan yang terkait dengan pemenuhan prinsip keadilan pemilu (electoral justice). ${ }^{8}$

Permasalahan terbesarnya adalah ketidaksesuaian kerangka pengaturan pemilu dengan paradigma keadilan pemilu. Seharusnya kerangka pengaturan pemilu yang disusun mampu memberikan perlindungan terhadap hak elektoral dan jika hak tersebut terlanggar dapat dipulihkan. Namun, kerangka pengaturan pemilu yang ada justru tidak efektif menjaga suara pemilih sebagai sumber kedaulatan. Kerangka pengaturan pemilu lebih menonjolkan penghukuman tanpa mampu mengembalikan suara pemilih.

Penyelenggara pemilu yang berintegritas berarti mengandung unsur penyelenggara yang jujur, transparan, akuntabel, cermat dan akurat dalam melaksanakan tugas dan kewenangannya. Integritas penyelenggara menjadi penting. Padahal salah satu tolak ukur terciptanya pemilu yang berintegritas dalam ACE (Administrasion and Cost of Election), adalah terjaminnya hak electoral seseorang yang disertai dengan penyelenggara pemilu yang berintegritas

\footnotetext{
6 Jujur berarti pemilihan umum harus dilaksanakan sesuai dengan aturan untuk memastikan bahwa setiap warga negara yang memiliki hak dapat memilih sesuai dengan kehendaknya dan setiap suara pemilih memiliki nilai yang sama untuk menentukan pemimpin yang akan terpilih.

7 Adil berarti perlakuan yang sama terhadap peserta pemilihan umum dan pemilih tanpa ada pengistimewaan ataupun diskriminasi terhadap peserta atau pemilih.

${ }^{8}$ Yusdar. 2010. Analisis Hukum Penggunaan Kartu Tanda Penduduk, Kartu Keluarga, dan Paspor Sebagai Tanda Pemilih dalam Pemilu Presiden dan Wakil Presiden Tahun 2009 di Indonesia (Studi Kasus Putusan Mahkamah Konstitusi Nomor 102/PUU-VII/2009). Jurnal Konstitusi Pusat Kajian Konstitusi Universitas Hasanuddin.
} 
dalam artian penyelenggara yang jujur, transparan, akuntabel, cermat dan akurat dalam melaksanakan tugas dan kewenangannya.

Indonesia sebagai salah satu negara demokrasi terbesar di dunia telah menetapkan enam ukuran pemilu yang demokratis yakni langsung, umum, bebas, rahasia, jujur dan adil. Hal itu termuat dalam pasal 22E ayat (1) Undang Undang Dasar NRI Tahun 1945. Selanjutnya, Pasal 3 Undang-Undang Nomor 7 Tahun 2017 tentang Pemilihan Umum menetapkan prinsip penyelenggaraan pemilihan umum, diantaranya : mandiri, jujur, adil, berkepastian hukum, tertib, terbuka, proporsional, profesional, akuntabel, efektif, dan efesien. Jika kita komparasikan syarat pemilu demokratis dengan kewenangan penyelenggara pemilu menurut Undang-Undang Nomor 7 Tahun 2017 tentang Pemilihan Umum maka penyelenggara pemilu mempunyai potensi untuk mewujudkan berbagai persyaratan tersebut diatas dalam tahapan pemilu.

Dalam praktiknya pengaturan penyelenggaraan pemilu, pemilu yang diselenggarakan di Indonesia hanya sekedar "desakan" memenuhi syarat prosedural akan tetapi mengesampingkan syarat substansial. Oleh karena itu, sebagai negara hukum, Indonesia sudah masanya melakukan perbaikan pengaturan pemilu yang menekankan pada syarat substansial terhadap pemilu. Standar yang dimaksud adalah standar yang diakui secara Internasional dan menjadi rujukan untuk melihat sebuah pemilu yang demokratis demi terwujudnya pemilu berintegritas adalah standar yang ditetapkan oleh International Institute for Democracy and Electoral Assistance (International IDEA). ${ }^{9}$

Berdasarkan uraian tersebut, maka penulis tertarik untuk membahasnya lebih lanjut dalam sebuah karya tulis ilmiah dengan Judul Ambivalensi Pengaturan

\section{Pemilihan Umum di Indonesia.}

\footnotetext{
${ }^{9}$ Standar Internasional Penyelenggaraan Pemilu menurut IDEA dapat diakses di laman https://www.idea.int/publications/pub_electoral_main.html, atau lihat pula seri buku panduan Standar-Standar Internasional untuk Pemilihan Umum, Pedoman Peninjauan Kembali Kerangka Hukum Pemilu, 2002, International IDEA, SE 10334 Sdtockholm, Sweden.
} 
Jurnal Al-Adalah: Jurnal Hukum dan Politik Islam

Vol. 4, No. 1, Januari 2019: 21-32

P-ISSN: 2406-8802

E-mail: aladalah@iain-bone.ac.id

http://jurnal.iain-bone.ac.id/index.php/aladalah

\section{B. Metode Penelitian}

\section{a. Tipe Penelitian}

Tipe Penelitian yang penulis gunakan dalam penelitian ini adalah penelitian hukum normatif (normative legal research) disebut juga penelitian kepustakaan, ada juga yang menyebut penelitian hukum doktrinal. Penelitian ini dilakukan dengan meneliti bahan hukum primer dan bahan hukum sekunder. Adapun penggunaan data dalam penelitian ini hanya untuk menunjang penelitian hukum normatif.

\section{b. Pendekatan Penelitian}

Untuk menemukan jawaban atas berbagai pertanyaan yang terkandung dalam rumusan masalah penelitian hukum ini, Penulis menggunakan beberapa pendekatan, yaitu: Pendekatan perundang-undangan(statute approach), pendekatan konseptual (conceptual approach), pendekatan kasus (case approach).

\section{c. Sumber Bahan Hukum}

Sumber bahan hukum yang digunakan dalam penelitian ini adalah berupa bahan hukum primer dan bahan hukum sekunder.

\section{d. Metode Analisis Bahan Hukum}

Metode analisis bahan hukum yang digunakan adalah metode analisis normatif kualitatif.

\section{Hasil Penelitian dan Pembahasan}

Menurut Aristoteles yang memerintah dalam suatu negara bukanlah manusia melainkan pikiran yang adil dan kesusilaanlah yang menentukan baik atau buruknya suatu hukum. Menurut Aristoteles, suatu negara yang baik adalah 
negara yang diperintah dengan konstitusi dan berkedaulatan hukum. Ia menyatakan ${ }^{10}$ :

"Constitutional rule in a state is closely connected,also with the requestion whether is better to be rulled by the best men or the best law,since a goverment in accordinace with law,accordingly the supremacy of law is accepted by Aristoteles as mark of good state and not merely as an unfortunate neceesity."

Artinya: Aturan konstutitusional dalam suatu negara berkaitan secara erat, juga dengan mempertanyakan kembali apakah lebih baik diatur oleh manusia yang terbaik sekalipun atau hukum yang terbaik, selama pemerintahan menurut hukum. Oleh sebab itu, supremasi hukum diterima oleh Aristoteles sebagai pertanda negara yang baik dan bukan semata-mata sebagai keperluan yang tidak layak.

Aristoteles juga mengemukakan tiga unsur dari pemerintahan berkonstitusi. Pertama, pemerintah dilaksanakan untuk kepentingan umum. Kedua, pemerintahan dilaksanakan menurut hukum yang berdasarkan ketentuanketentuan umum, bukan hukum yang dibuat secara sewenang-wenang yang mengesampingkan konvensi dan konstitusi. Ketiga, pemerintahan berkonstitusi yanga dilaksanakan atas kehendak rakyat. Pemikiran Aristoteles tersebut diakui merupakan cita negara hukum yang dikenal sampai sekarang. Menurut hemat penulis, bahwa apa yang dikemukakan oleh Aristoteles merupakan bahan kajian pada Karya Ilmiah ini karena terkait keteraturan hukum.

Demokrasi adalah rambu untuk melihat dan menandai praktik penyelenggaraan negara agar tidak melanggar batas-batas kekuasaan negara sehingga memicu resiko penyalagunaan kekuasaan (abouse of power). Selain bahwa dalam kontitusi kita dapat melihat sekaligus mengukur indikator keberhasilan dan kegagalan negara dalam memberikan perlindungan terhadap

10 George Sabine, A History of Political Theory, George G. Harrap \& CO.Ltd., London,1995, hal.92, juga Dahlan Thaib, Kedaulatan Rakyat, Negara Hukum dan Hak- hak Asai Manusia. hal.22 
Jurnal Al-Adalah: Jurnal Hukum dan Politik Islam

Vol. 4, No. 1, Januari 2019: 21-32

P-ISSN: 2406-8802

E-mail: aladalah@iain-bone.ac.id

http://jurnal.iain-bone.ac.id/index.php/aladalah

hak-hak dasar rakyat, termasuk dalam jaminan demokrasi dan hak asasi manusia. Demokrasi dan hak asasi manusia merupakan basic norm dalam kehidupan bernegara $^{11}$. Menurut Moh. Kusnardi dan Harmaily Ibrahim ${ }^{12}$ secara garis besar pemilihan umum terdapat dua model berkaitan dengan sistem pengisian keanggotaan lembaga perwakilan rakyat yang cukup banyak penganutnya, yaitu sistem oraganis dan sistem mekanis. Sedangkan, menurut Bagir Manan, Pemilihan umum yang diadakan dalam siklus lima (5) tahun sekali merupakan saat atau momentum memperlihatkan secara nyata dan langsung pemerintahan oleh rakyat. Pada saat pemilihan umum itulah semua calon yang ingin duduk sebagai penyelenggara negara dan pemerintahan bergantung sepenuhnya pada keinginan atau kehendak rakyat ${ }^{13}$. Regulasi tentang pemilihan umum mengalami suatu paradigma yang bersifat dinamis. Hal ini sejalan dengan perkembangan pemikiran para elit politik, para pakar, dan tentu pula beriringan dengan aspirasi akar rumput (masyarakat). Pemilihan umum di Indonesia pada zaman orde baru ditujukan untuk memilih anggota lembaga legislatif, yaitu Dewan Perwakilan Rakyat, Dewan Perwakilan Rakyat Daerah Provinsi, dan Dewan Perwakilan Rakyat Daerah Kabupaten/Kota.

Pasca reformasi dan amandemen UUD $1945^{14}$ pemilihan umum di Indonesia dilaksanakan secara langsung, umum, bebas, rahasia, jujur, dan adil setiap lima tahun sekali ${ }^{15}$ yang dimaksudkan untuk memilih anggota Dewan Perwakilan Rakyat, Dewan Perwakilan Daerah, Presiden dan Wakil Presiden dan

${ }^{11}$ Anshori Ilyas. 2010. Suara Terbanyak dan Ambivalensi Demokrasi: Analisis atas Putusan Mahkamah Konstitusi Nomor: 22/PUU-VI/2008. Pada Jurnal Konstitusi Pusat Kajian Konstitusi Universitas Hasanuddin, Makassar. Volume I, Nomor 1, November 2009.

${ }^{12}$ Moh. Kusnardi dan Harmaily Ibrahim. 1983. Pengantar Hukum Tata NegaraIndonesia. CV. Sinar Bakti: Jakarta. Hal. 333.

${ }^{13}$ Bagir Manan. 1994. Pelaksanaan Demokrasi Pancasila Dalam Pembangunan Jangka Panjang (PJP) II. Makalah pada lokakarya Pengajar Pancasila di lingkungan Universitas Padjadjaran, Bandung.

${ }^{14}$ Amandemen sebanyak empat kali : amandemen pertama pada tanggal 19 Oktober 1999, amandemen kedua pada tanggal 18 Agustus 2000, amandemen ketiga pada tanggal 10 November 2001, dan amandemen keempat pada tanggal 10 Agustus 2002. Penyebutan UUD 1945 diganti menjadi UUD NRI Tahun 1945, sebagaimana ditegaskan dalam aturan tambahan Pasal II “dengan ditetapkannya UUD ini, UUD NRI Tahun 1945 terdiri atas pembukaan dan pasal-pasal”. (Lihat : Harmailiy Ibrahim, 1987, Hukum Tata Negara Indonesia, UI, Jakarta, hal. 98)

${ }^{15}$ Pasal 22E ayat (1) UUD NRI Tahun 1945 
Dewan Perwakilan Rakyat Daerah yang diselenggarakan oleh suatu komisi pemilihan umum yang bersifat nasional, tetap, dan mandiri.

Amanat konstitusi tersebut untuk memenuhi tuntutan perkembangan kehidupan politik, dinamika masyarakat dan perkembangan demokrasi yang sejalan dengan pertumbuhan kehidupan berbangsa dan bernegara. Di samping itu, wilayah Negara Republik Indonesia yang luas dengan jumlah penduduk yang besar dan menyebar di seluruh nusantara serta memiliki kompleksitas nasional menuntut penyelenggara pemilihan umum yang mempunyai integritas.

Pemilihan umum secara langsung oleh rakyat merupakan sarana perwujudan kedaulatan rakyat guna menghasilkan pemerintahan negara yang demokratis berdasarkan Pancasila dan UUD NRI Tahun 1945. Penyelenggaraan pemilihan umum secara langsung, umum, bebas, rahasia, jujur dan adil dapat terwujud apabila dilaksanakan melalui konsep yang tepat karena penyelenggaraan pemilihan umum di Indonesia saat sekarang ini masih sebatas penyelengaraan pemilihan umum demokrasi prosedural, belum mencerminkan penyelenggaraan pemilihan umum demokrasi substansial karena sebagaimana dalam beberapa ketentuan perundang-undangan hanya tataran penyelenggara pemilihan umum yang dituntut untuk professional serta mempunyai integritas, kapabilitas, dan akuntabilitas.

Idealnya, penyelenggaraan pemilihan umum adalah salah satu syarat berlangsungnya demokrasi. Namun, tidak semua pemilihan umum berlangsung secara demokratis ${ }^{16}$. Sesungguhnya ada beberapa prinsip dalam ACE (2012) yang juga dibutuhkan untuk mewujudkan pemilu yang berintegritas, yaitu: (1) Menghormati prinsip-prinsip pemilu yang demoktaris; (2) Kode etik, integritas pemilu juga bergantung pada perilaku etis para penyelenggara pemilu, kandidat, partai dan semua peserta dalam proses pemilu; (3) Profesionalisme dan akurasi, pemilu yang berintegritas sering diasumsikan berasal dari praktik pemilu yang jujur; (4) Perlindungan terhadap lembaga penyelenggara pemilu. Untuk menjamin adanya pemilu yang berintegritas, ada baiknya jika lembaga penyelenggara

${ }^{16}$ Didik Supriyanto. 2007. Menjaga Independensi Penyelenggara Pemilu. Perludem: Jakarta. hal. 22 
Jurnal Al-Adalah: Jurnal Hukum dan Politik Islam

Vol. 4, No. 1, Januari 2019: 21-32

P-ISSN: 2406-8802

E-mail: aladalah@iain-bone.ac.id

http://jurnal.iain-bone.ac.id/index.php/aladalah

pemilu berdiri sendiri dan mandiri dalam melaksanakan proses pemilu; (5) Pengawasan dan penegakan hukum. Fungsi dari pengawasan dan kerangka hukum adalah supaya penyelenggara dan peserta pemilu bertanggung jawab terhadap proses pemilu; dan (6) Transparan dan akuntabel, transparansi penyelenggara dalam memberikan informasi kepada publik tentang semua proses pemilu adalah salah satu upaya dalam mewujudkan pemilu yang berintegritas.

Langkah-langkah mewujudkan pemilu yang berintegritas disesuaikan dengan konteks sosial dan politik dimasing-masing negara, namun tujuannya tetap sama yaitu menjamin berlangsungnya pemilu yang jujur dan adil. Terdapat delapan kriteri pemilu berintegritas yang dirumuskan Ramlan Subakti ${ }^{17}$, yaitu: (1) Hukum pemilu dan kepastian hukum; (2) Kesetaraan antar warga negara, baik dalam pemungutan dan penghitungan suara maupun dalam alokasi kursi DPR/DPRD dan pembentukan daerah pemilihan; (3) Persaingan bebas dan adil; (4) Partisipasi pemilih dalam pemilu; (5) Penyelenggara pemilu yang mandiri, kompetensi, berintegritas, efesien dan kepemimpinan yang efektif; (6) Proses pemungutan dan penghitungan suara berdasarkan asas pemilu demokratik dan prinsip pemilu berintegritas; (7) Keadilan pemilu; dan (8) Tidak ada kekerasaan dalam proses pemilu. Kekerasan pemilu adalah setiap tindakan yang mencederai orang atau ancaman mencederai yang berkaitan dengan pemilu.

Makna pemilu berkualitas dan berintegritas pada dasarnya telah terangkum dalam pengertian pemilu demokratis yang mensyaratkan minimal dua hal yakni bebas dan adil atau free and fair election. Namun perkembangan demokrasi yang sangat dinamis, membuat banyak pihak tidak puas dengan dua kriteria demokrasi tersebut.

Electoral Integrity Group yang beranggotakan 15 pensiunan hakim agung dan mantan penyelenggara pemilu dari 13 negara, termasuk dari Indonesia mengajukan keadilan pemilu sebagai parameter pemilu demokratis. Keadilan pemilu, menurut Electoral Integrity Group, yang dideklarasikan dengan judul

\footnotetext{
${ }^{17}$ Ramlan Surbakti. 2014. Understanding the Flaws in Indonesia's Electoral Democracy, dalam Strategic Review, The Indonesian Journal of Leadership, Policy and World Affairs, Volume 4, Number 1 January-March 2014.
} 
Towards an International Statement of Principles of Electoral Justice di Accra, Ghana, 15 September 2011 terdiri atas 10 prinsip.

Rangkaian penyelenggaraan pemilu akan dapat dikategorikan berdasarkan keadilan jika : (1) integritasnya tinggi; (2) melibatkan banyak warga; (3) berdasarkan hukum yang berkepastian tinggi; (4) imparsial dan adil; (5) profesional dan independen; (6) transparan; (7) tepat waktu sesuai dengan rencana; (8) tanpa kekerasan atau bebas dari ancaman dan kekerasan; (9) teratur; (10) peserta pemilu menerima wajar kalah atau menang.

Pada saat ini dalam era transisional menuju sebuah negara demokrasi yang sesungguhnya, maka perbaikan secara substansial terhadap pemilu perlu dilakukan. Standar yang diakui secara internasional dan menjadi rujukan untuk melihat apakah sebuah pemilu sudah demokratis adalah standar yang dibuat oleh International Institute for Democracy and Electoral Assistance (International IDEA). Berdasarkan rujukan tersebut, ada 15 aspek yang dijadikan ukuran untuk melihat Pemilu yang demokratis, meliputi: (1). Penyusunan Kerangka Hukum; (2) Pemilihan Sistem Pemilu; (3) Penetapan Daerah Pemilihan; (4) Hak untuk memilih dan dipilih; (5) Badan Penyelenggara Pemilu; (6) Pendaftaran Pemilih dan Daftar Pemilih; (7) Akses Kertas Suara bagi Partai Politik dan Kandidat; (8) Kampanye Pemilu yang Demokratis; (9) Akses Media dan Kebebasan Berekspresi; (10) Pembiayaan dan Pengeluaran; (11) Pemungutan Suara; (12) Penghitungan dan Rekapitulasi Suara; (13) Peranan Wakil Partai dan Kandidat; (14) Pemantau Pemilu; (15) Kepatuhan terhadap Hukum dan Penegakan Peraturan Pemilu.

Integritas penyelenggaraan pemilu yang secara konsepsional dapat dilihat dari perspektif manajemen organisasi penyelenggara pemilu yang tertib dan profesional baik dalam kerangka mengelola dan menjalankan peraturan pemilu yang meliputi pengaturan teknis operasional tahapan dalam bentuk perumusan peraturan internal Komisi Pemilihan Umum (KPU) dan Badan Pengawas Pemilu (Bawaslu) serta dalam penegakan kode etik penyelenggara pemilu diawasi oleh Dewan Kehormatan Penyelenggara Pemilu (DKPP). Penegakkan kode etik penyelenggara pemilu adalah bagian substansial dalam membangun kualitas 
Jurnal Al-Adalah: Jurnal Hukum dan Politik Islam

Vol. 4, No. 1, Januari 2019: 21-32

P-ISSN: 2406-8802

E-mail: aladalah@iain-bone.ac.id

http://jurnal.iain-bone.ac.id/index.php/aladalah

pemahaman dan menanamkan kesadaran etika bagi penyelenggara pemilu mengenai pentingnya melaksanakan tugas dan fungsi secara profesional dan independen serta adanya ketaaatan terhadap asas penyelenggaraan pemilihan umum oleh para peserta dan masyarakat. Dalam pelaksanaan tahapan pemilu diperlukan integritas ${ }^{18}$ dari para stacholders.

Dengan menekankan pada upaya pengembangan integritas di bidang pengawasan diyakini akan melahirkan kinerja pengawasan pemilu yang semakin dihormati semua pihak. Dengan demikian, akan mendorong semua pihak untuk menghormati semua lembaga yang terlibat dalam proses penyelenggaraan dan menetapkan hasil pemilu.

\section{Kesimpulan}

Pemilihan umum secara langsung oleh rakyat merupakan sarana perwujudan kedaulatan rakyat guna menghasilkan pemerintahan negara yang demokratis berdasarkan Pancasila dan UUD NRI Tahun 1945. Dalam pelaksanaan pemilu diperlukan pengaturan pemilu yang tidak sebatas pengaturan pada aspek prosedural tetapi adalah penekanan pada aspek integritas menjadi substansi yang sangat penting. Oleh karena, kata integritas dalam pemilu yang demokratis merupakan kata kunci untuk keberhasilan dalam pelaksanaan pemilu sehingga perlu ada pemahaman bersama (common platform) mengenai platform tersebut. Terselenggaranya penyelenggaraan pemilu yang berintegritas tidak hanya sebagai tuntutan penyelenggara pemilu tetapi juga merupakan tuntutan kepada peserta pemilu serta terlebih tuntutan terhadap masyarakat. Idelanya, pengaturan pemilihan umum di Indonesia tidak hanya menekankan pada standar penyelenggaraan secara prosedural, tatapi terlebih penting adalah penekanan pada

18 Integritas dapat diartikan sebagai sebuah konsep memiliki keterkaitan dengan konsistensi (consistency), tindakan (actions), nilai-nilai (value), metode (methods), ukuran-ukuran (measures), prinsip-prinsip (prinsiciples), harapan (expectation) dan capaian (outcome). Pada umumnya terminologi integritas digunakan sebagai konsep yang holistik, memastikan (judging) integritas sebuah sistem dengan parameter yang dikembangkan sendiri mampu mencapai (ability to acvieve) tujuan (goal) yang dirumuskan sendiri. Ada juga yang melihat integritas sebagai kualitas (quality) dalam memiliki sense of honesty dan truthfulness yang memotivasi adanya sebuah tindakan. Sedangkan secara etimologis, kosa kata integritas berasal dari bahasa latin integer yang artinya whole atau complete (menyeluruh atau lengkap). Dalam konteks ini integritas dapat dibandingkan dengan personal inner sense dari "wholeness" sebagai derivasi dari say (perkataan) yang honest (jujur) dan consistency (konsistensi) dari karakter. 
standar substansial. Hal ini penting di lakukan perbaikan demi terwujudnya kerangka pengaturan pemilu yang mampu mewujudkan penyelenggaraan pemilu berintegritas.

\section{Daftar Pustaka}

Anshori Ilyas. 2010. Suara Terbanyak dan Ambivalensi Demokrasi: Analisis atas Putusan Mahkamah Konstitusi Nomor: 22/PUU-VI/2008. Pada Jurnal Konstitusi Pusat Kajian Konstitusi Universitas Hasanuddin, Makassar. Volume I, Nomor 1, November 2009.

Bagir Manan. 1994. Pelaksanaan Demokrasi Pancasila Dalam Pembangunan Jangka Panjang (PJP) II. Makalah pada lokakarya Pengajar Pancasila di lingkungan Universitas Padjadjaran, Bandung.

Didik Supriyanto. 2007. Menjaga Independensi Penyelenggara Pemilu. Perludem: Jakarta.

Moh. Kusnardi dan Harmaily Ibrahim. 1983. Pengantar Hukum Tata Negara Indonesia. CV. Sinar Bakti: Jakarta.

Ramlan Surbakti. 2014. Understanding the Flaws in Indonesia's Electoral Democracy, dalam Strategic Review, The Indonesian Journal of Leadership, Policy and World Affairs, Volume 4, Number 1 JanuaryMarch 2014.

Yusdar. 2010. Analisis Hukum Penggunaan Kartu Tanda Penduduk, Kartu Keluarga, dan Paspor Sebagai Tanda Pemilih dalam Pemilu Presiden dan Wakil Presiden Tahun 2009 di Indonesia (Studi Kasus Putusan Mahkamah Konstitusi Nomor 102/PUU-VII/2009). Jurnal Konstitusi Pusat Kajian Konstitusi Universitas Hasanuddin.

\section{Undang-Undang}

Undang-Undang Dasar Negara Republik Indonesia Tahun 1945

Undang-UndangNomor 7 Tahun 2017 tentang Pemilihan Umum (Lembaran Negara Republik Indonesia Tahun 2017 Nomor 182, Tambahan Lembaran Negara Nomor 6109) 